\title{
Food Processing Workers
}

National Cancer Institute

\section{Source}

National Cancer Institute. Food Processing Workers. NCI Thesaurus. Code C122461.

Workers who operate equipment that mixes, cooks, or processes ingredients used in the manufacturing of food. 